CASSOWARY volume 4 (2) Juni 2021: 133-138

ISSN : 2614-8900

E-ISSN : 2622-6545

Program Pascasarjana Universitas Papua, https://pasca.unipa.ac.id/

\title{
Pertumbuhan dan produksi beberapa mutan kedelai Kipas Merah generasi ke lima di kebun percobaan Lampahan Bener Meriah
}

\author{
Fahmil Huda, Ainun Marliah, Erita Hayati, Hasanudin dan Zuyasna* \\ ${ }^{1}$ Jurusan Agroteknologi, Fakultas Pertanian, Universitas Syiah Kuala \\ Jln.T.H. Krueng Kalee. No 3. Darussalam. Banda Aceh, 23111, Indonesia. \\ *Email: zuyasna@unsyiah.ac.id
}

Disubmit: 31 Maret 2021, direvisi: 26 Mei 2021, diterima: 30 Mei 2021

Doi: https://doi.org/10.30862/casssowary.cs.v4.i2.99

\begin{abstract}
The research objective was to determine the growth and production of the fifth generation mutant soybean $\left(\mathrm{M}_{5}\right)$ at the Lampahan Bener Meriah University Farm. This study used a non-factorial randomized block design (RBD) with three replications, where four genotypes of Kipas Merah mutants were tested and compared with Kipas Merah (their parents) and Grobogan variety (large seeds). The variables observed were plant height, number of branches, number of productive branches, days of flowering, number of pods, number of pithy pods, number of seeds, weight of seeds per plant and weight of 100 seeds. The results of this study indicate that the $\mathrm{M}_{5}$ mutant soybean genotype has no significant different on plant height at age 4, 6, 8 WAP, number of branches per plant aged 6, $8 \mathrm{WAP}$, number of pods, and number of productive branches per plant. The highest average plant height and the highest number of productive branches found in Kipas Merah (G0) varieties. Mutant soybean genotype $\mathrm{M}_{5}$ had a very significant effect on flowering age and seed weight per plot. The fastest flowering was Kipas Merah (G0) and the latest flowering was A11 (G4) and A14 (G5) mutants. The highest weight of 100 seeds found in mutant A11 (G4) about $18.585 \mathrm{~g}$ and no significant different with Grobogan variety (18.827 g). The highest seed weight per plot found in mutant A11 (G4) about $169.35 \mathrm{~g}$. Based on the results of this study, mutant A11 (G4) was the best growth and production of the tested M5 genotypes.
\end{abstract}

Keywords: mutagenesis, soybean breeding, radiation, gamma rays

\section{PENDAHULUAN}

Kebutuhan kedelai sebagai sumber pangan langsung maupun sebagai bahan baku industri di Indonesia setiap tahunnya terus mengalami peningkatan, sementara produksi kedelai masih rendah bahkan terus menurun (Handara et $a l,$. 2014). Kementerian Pertanian (2020) mengemukakan bahwa produksi kedelai tahun 2019 mengalami penurunan dari tahun 2018 menjadi 424,18 ribu ton.
Penurunan produksi kedelai terjadi karena adanya penurunan luas panen yang disebabkan oleh menurunnya luas tanam, masih rendahnya minat petani, dan kurang tersedianya benih kedelai pada saat musim tanam tiba.

Beberapa cara yang dapat dilakukan untuk meningkatkan produksi kedelai yaitu dengan memperbaiki sistem budidaya tanaman secara optimal, 
yaitu penggunaan benih bermutu dari varietas unggul, pengendalian hama penyakit tanaman, pengaturan irigasi dan teknik budidaya serta pemupukan. Upaya untuk mendapatkan kedelai varietas unggul dapat dilakukan melalui kegiatan pemuliaan tanaman.

Kegiatan pemuliaan pada tanaman kedelai dilakukan untuk memperbaiki potensi hasil dan karakter agronomi, peningkatan komposisi biji, peningkatan toleransi terhadap cekaman abiotik, dan toleransi terhadap herbisida, serta perbaikan resistensi terhadap hama dan penyakit (Syukur et al., 2012). Menurut Purba et al. (2013), peningkatan produksi suatu tanaman juga dapat dilakukan melalui usaha pemuliaan tanaman yaitu dengan induksi mutasi. Mutasi bisa dihasilkan oleh beberapa agen mutagenik seperti radiasi, non-radiasi maupun kimia. Sumber radiasi yang sering digunakan adalah sinar $\mathrm{X}$, sinar- gamma dan ultra-violet.

Pembentukan varietas unggul kedelai yang sesuai pada tipe lahan agroekosistem target memerlukan sumber-sumber gen dari sifat yang diinginkan yang diperoleh dari plasma nutfah yang dimiliki. Salah satu varietas kedelai asal Aceh adalah kedelai Kipas Merah. Kelebihan dari varietas ini adalah mampu tumbuh dan berkembang pada lahan kering atau tegalan baik dataran rendah maupun perbukitan, pada sawah tadah hujan dan irigasi setelah panen padi, tumbuh pada daerah beriklim tipe zona C2 sampai E2. Varietas Kipas Merah berpotensi menjadi varietas unggul yang sesuai dengan kondisi lahan di Aceh.

Zuyasna et al. (2016) telah melakukan mutagenesis pada varietas Kipas merah menggunakan radiasi sinar gamma pada tahun 2013 dan telah dilakukan seleksi pada beberapa galur yang berpotensi untuk dikembangkan lebih lanjut menjadi varietas unggul.
Berdasarkan hal tersebut perlu dilakukan penelitian untuk melihat potensi produksi mutan-mutan kedelai Kipas Merah generasi ke lima di daerah Kabupaten Bener Meriah.

\section{MATERI DAN METODE}

Penelitian ini dilaksanakan di Kebun Percobaan University Farm Lampahan Kecamatan Timang Gajah Kabupaten Bener Meriah. Bahan yang digunakan dalam penelitian ini adalah empat galur mutan kedelai Kipas Merah generasi ke5, varietas Kipas Merah dan Grobogan, pupuk kandang, furadan, dan abu sekam padi bakar. Penelitian ini menggunakan rancangan acak kelompok (RAK) pola non-faktorial, terdiri dari 3 ulangan sehingga ada 18 unit satuan percobaan. Pada masing-masing perlakuan diamati 5 tanaman sampel yang diambil dari 25 tanaman perplot. Untuk mengetahui pengaruh genotipe yang dicobakan digunakan uji F. Bila pada Anova menunjukkan pengaruh yang nyata atau sangat nyata, maka dilanjutkan dengan uji beda nyata terkecil pada taraf 5\% (BNT 0, 05\%). Peubah yang diamati yaitu: tinggi tanaman, jumlah cabang pertanaman, umur tanaman berbunga, jumlah cabang produktif, jumlah polong pertanaman, jumlah polong bernas, jumlah biji pertanaman, berat biji perbedeng dan berat 100 biji.

\section{HASIL DAN PEMBAHASAN}

Hasil uji $\mathrm{F}$ terhadap tinggi tanaman, jumlah cabang pertanaman, dan jumlah cabang produktif pertanaman tidak berpengaruh nyata pada genotipe yang diuji. Rerata tinggi tanaman umur 4, 6, dan 8 MST cenderung lebih tinggi pada Kipas Merah (G0), walaupun secara statistika berbeda tidak nyata dengan tinggi tanaman kedelai varietas Grobogan (G1), mutan A1 (G2), A7 (G3), A11 (G4) dan A14 (G5). Untuk lebih jelas rerata tinggi tanaman kedelai yang diuji pada umur 4, 
6, 8 MST dapat dilihat pada gambar 1 . Menurut Purba et al, (2013) pengaruh radiasi sinar gamma dapat menyebabkan tanaman kedelai lebih pendek dari pada tetuanya. Kemungkinan hal ini disebabkan oleh mutasi yang terjadi mengakibatkan metabolisme protein terganggu, menghambat aktivitas pembelahan dan perpanjangan sel-sel meristem dan pertumbuhan tanaman akan terganggu.

Rerata jumlah cabang per tanaman kedelai umur 6 dan 8 MST relatif lebih tinggi diperoleh pada genotype A7 (G3), walaupun secara statistika tidak berbeda nyata dengan genotipe lain yang diuji seperti disajikan pada gambar 2. Jumlah cabang produktif pertanaman kedelai cenderung lebih tinggi pada tanaman tetua Kipas Merah (G0), walaupun secara statistika tidak berbeda nyata dengan genotype lain yang diuji, seperti disajikan pada gambar 3. Jumlah cabang dan jumlah cabang produktif tidak berbeda nyata kemungkinan disebabkan faktor genetik yang diuji dan kondisi lingkungan yang terus menerus kemarau.
Hal ini sesuai dengan pendapat Rahmat et al. (2018) bahwa penampilan suatu tanaman tidak menunjukkan sifat yang dibawanya (faktor genetik) kecuali ada faktor lingkungan yang menunjang. Karakter morfologi tanaman yang bervariasi merupakan hasil dari pengaruh yang terjadi antara genetik tanaman dengan lingkungannya.

Rerata umur berbunga kedelai tercepat diperoleh pada varietas Kipas merah (G0) yang berbeda nyata dengan mu$\tan \mathrm{A} 1$ (G2), A7 (G3), A11 (G4) dan A14 (G6), namun berbeda tidak nyata dengan umur berbunga kedelai varietas Grobogan (G1). Bunga yang ada pada tanaman kedelai muncul dan tumbuh di bagian ruas-ruas batang dan ada juga tumbuh pada cabang yang memiliki daun. Menurut Adisarwanto (2014) potensi jumlah bunga yang tumbuh dan terbentuk tidak sama, bergatung dari varietas atau genotipe kedelai dan pada umumnya yang terdapat $40-200$ bunga pertanaman.

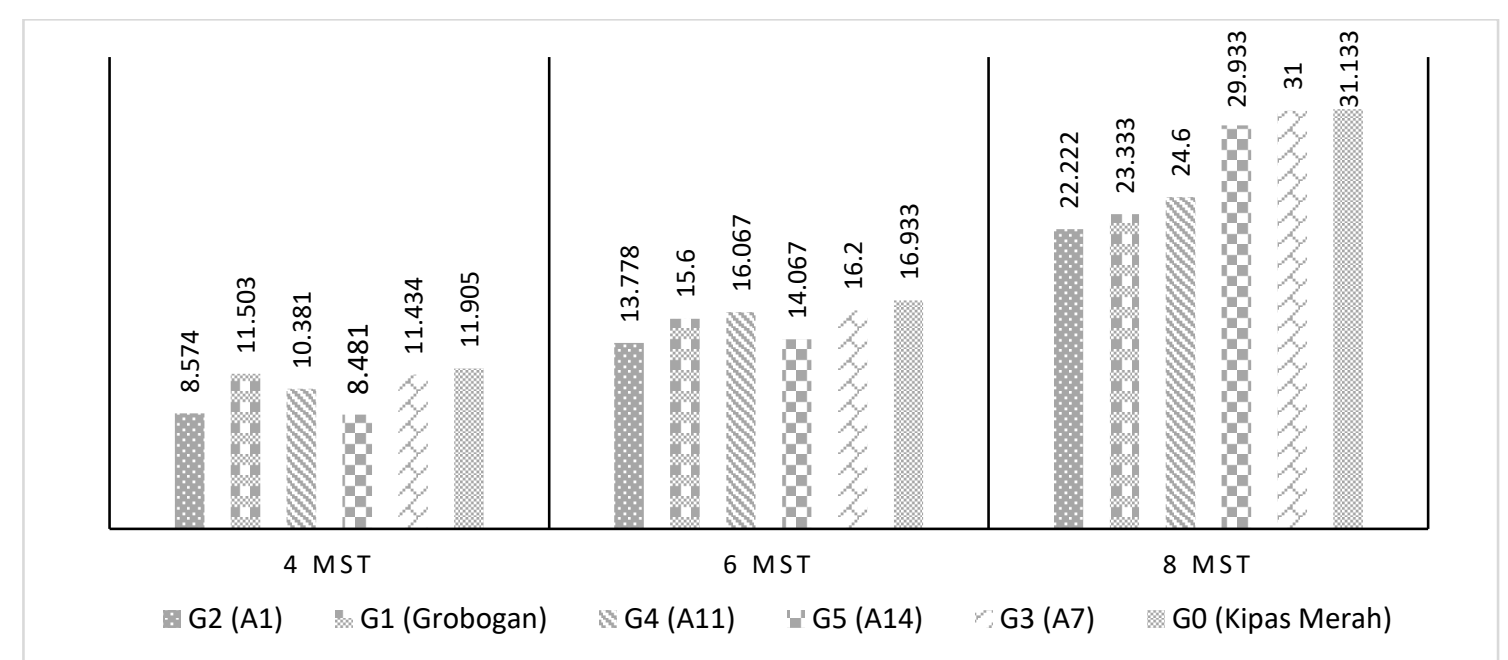

Gambar 1. Rerata tinggi kedelai genotype $\mathrm{M}_{5}$, tetua Kipas Merah dan varietas Grobogan pada umur 4, 6, 8 MST 


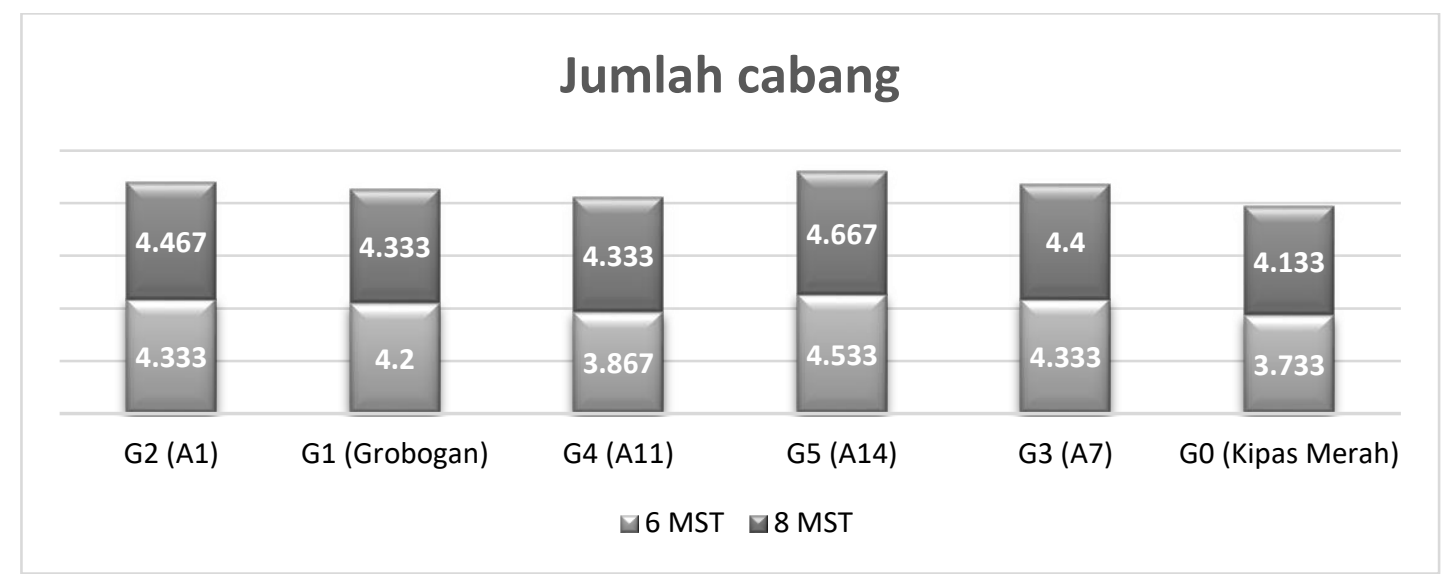

Gambar 2. Rerata jumlah cabang genotipe kedelai $\mathrm{M}_{5}$ tetua Kipas Merah dan varietas Grobogan pada umur 4, 6, 8 MST

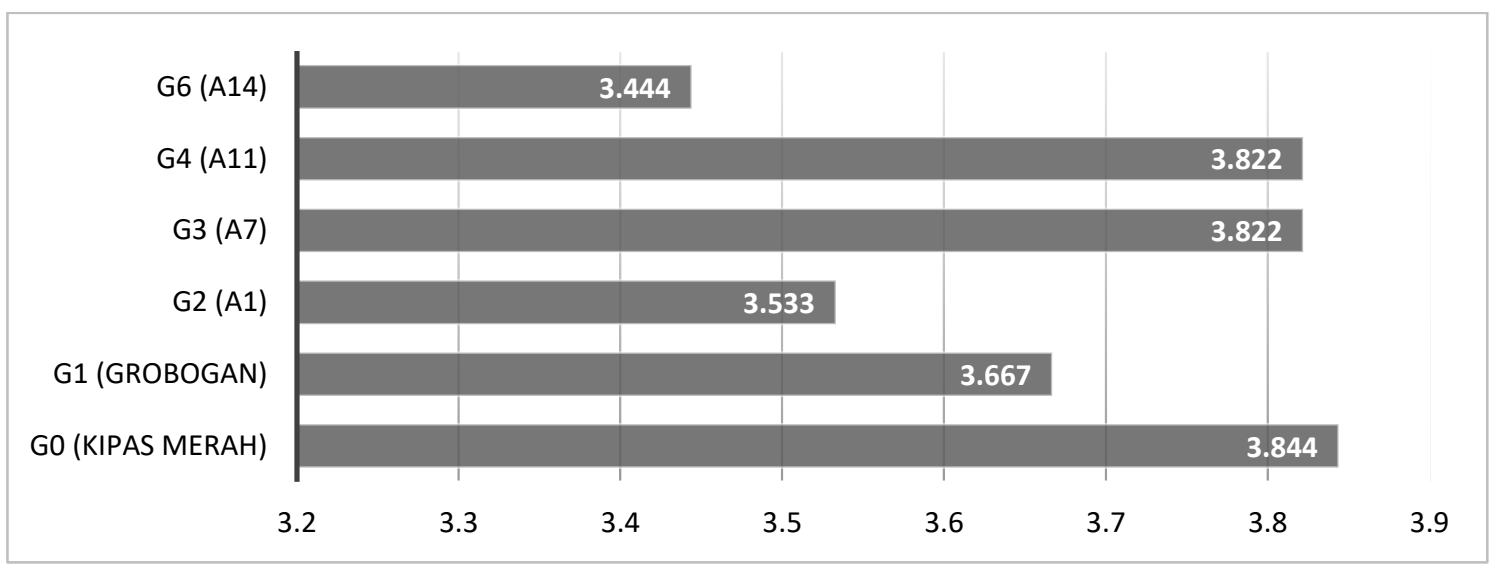

Gambar 3. Rerata jumlah cabang produktif genotipe kedelai $\mathrm{M}_{5}$, tetua Kipas Merah dan varietas Grobogan pada umur 4, 6, 8 MST

Tabel 1. Rerata umur berbunga kedelai beberapa genotipe mutan $\mathrm{M}_{5}$, tetua Kipas Merah dan varietas Grobogan

\begin{tabular}{lr}
\hline Umur berbunga & \\
Kipas Merah (G0) & $34,800 \mathrm{a}$ \\
Grobogan (G1) & $37,333 \mathrm{a}$ \\
Mutan A1 (G2) & $61,333 \mathrm{~b}$ \\
Mutan A7 (G3) & $61,333 \mathrm{~b}$ \\
Mutan A11 (G4) & $66,333 \mathrm{~b}$ \\
Mutan A14 (G5) & $66,333 \mathrm{~b}$ \\
BNT $_{0,05}=$ & 17,66 \\
$\mathrm{KK}^{2}$ & $17,77 \%$ \\
\hline
\end{tabular}

Genotipe mutan $\mathrm{M}_{5}$ berpengaruh tidak nyata terhadap jumlah polong per tanaman kedelai dan jumlah polong ber- nas kedelai (Tabel 2). Hal ini kemungkinan disebabkan karena kondisi lingkungan yang tidak mendukung seperti angin yang sangat kuat sehingga banyak bunga yang berguguran. Krisnawati (2017) berpendapat bahwa polong tanaman kedelai dipengaruhi oleh jumlah bunga yang terbentuk pada kondisi yang optimum.

Rerata jumlah polong bernas per tanaman cenderung lebih banyak diperoleh pada mutan A11 (G4), walaupun secara statistika berbeda tidak nyata dengan tetua Kipas Merah (G0) serta genotipe lainnya. Diduga hal ini disebabkan kondisi lingkungan seperti suhu, lama penyinaran dan intensitas cahaya pada lokasi yang digunakan tidak optimal untuk genotipe yang diuji. 
Rerata jumlah biji pertanaman dan berat biji pertanaman tidak berbeda nyata secara statistik pada semua perlakuan. Rerata jumlah biji terbanyak terdapat pada mutan A11 (G4) yaitu sebanyak 275,867 . Demikian juga halnya dengan berat biji per tanaman, tertinggi pada mutan A11 sebesar 48,852 g (Tabel 3).

Tabel 2. Rerata jumlah polong pertanaman dan jumlah polong bernas pertanaman pada beberapa beberapa genotipe mutan $\mathrm{M}_{5}$, tetua Kipas Merah dan varietas Grobogan

\begin{tabular}{lr}
\hline \multicolumn{2}{l}{ Jumlah polong pertanaman } \\
Kipas Merah (G0) & 58,533 \\
Grobogan (G1) & 24,000 \\
Mutan A1 (G2) & 46,556 \\
Mutan A7 (G3) & 60,067 \\
Mutan A11 (G4) & 92,933 \\
Mutan A14 (G5) & 79,400 \\
KK= & $47,12 \%$ \\
\hline Jumlah polong bernas pertanaman \\
Kipas Merah (G0) & 58,533 \\
Grobogan (G1) & 24,000 \\
Mutan A1 (G2) & 46,556 \\
Mutan A7 (G3) & 60,067 \\
Mutan A11 (G4) & 92,933 \\
Mutan A14 (G5) & 79,400 \\
KK= & $47,12 \%$ \\
\hline
\end{tabular}

Kedelai genotipe mutan $\mathrm{M}_{5}$ berpengaruh nyata terhadap berat biji per bedeng dan berat 100 biji (Tabel 3). Rerata berat biji kedelai per bedeng tertinggi di peroleh mutan A11 (G4) yang berbeda nyata dengan varietas Grobogan (G1), mutan A1 (G2) dan A7 (G3), namun berbeda tidak nyata dengan Kipas Merah (G0) dan mutan A14 (G6). Berat 100 biji kedelai tertinggi diperoleh pada mutan A11 (G4) yang berbeda nyata dengan tetua Kipas Merah (G0), G2 (A1), dan A14 (G6), namun berbeda tidak nyata dengan mutan A7 (G3), dan varietas Grobogan (G1). Peningkatan berat 100 biji tanaman pada mutan A11 dari tetuanya varietas Kipas Merah diduga karena adanya pengaruh radiasi yang dapat mempengaruhi karakter fisik biji yang merubah susunan genetik.

Tabel 3. Rerata jumlah biji pertanaman, berat biji pertanaman, berat biji perbedeng, berat 100 biji pada beberapa beberapa genotipe mutan $\mathrm{M}_{5}$, tetua Kipas Merah dan varietas Grobogan

\begin{tabular}{|c|c|}
\hline \multicolumn{2}{|c|}{ Jumlah Biji Per Tanaman } \\
\hline Kipas Merah (G0) & 176,800 \\
\hline Grobogan (G1) & 72,867 \\
\hline Mutan A1 (G2) & 140,222 \\
\hline Mutan A7 (G3) & 179,200 \\
\hline Mutan A11 (G4) & 275,867 \\
\hline Mutan A14 (G5) & 236,200 \\
\hline $\mathrm{KK}=$ & $47,33 \%$ \\
\hline \multicolumn{2}{|c|}{ Berat Biji PerTanaman (g) } \\
\hline Kipas Merah (G0) & 33,900 \\
\hline Grobogan (G1) & 18,031 \\
\hline Mutan A1 (G2) & 22,380 \\
\hline Mutan A7 (G3) & 32,608 \\
\hline Mutan A11 (G4) & 48,852 \\
\hline Mutan A14 (G5) & 35,609 \\
\hline $\mathrm{KK}=$ & $40,54 \%$ \\
\hline \multicolumn{2}{|c|}{ Berat Biji Per bedeng $(\mathrm{g})$} \\
\hline Kipas Merah (G0) & $144,630 \mathrm{ab}$ \\
\hline Grobogan $(\mathrm{G} 1)$ & $109,950 a$ \\
\hline Mutan A1 (G2) & $123,607 \mathrm{a}$ \\
\hline Mutan A7 (G3) & $137,263 \mathrm{a}$ \\
\hline Mutan A11 (G4) & $169,35 b$ \\
\hline Mutan A14 (G5) & $144,63 \mathrm{ab}$ \\
\hline $\mathrm{BNT}_{0,05}=$ & 12,35 \\
\hline $\mathrm{KK}=$ & $31,04 \%$ \\
\hline \multicolumn{2}{|l|}{ Berat 100 biji $(\mathrm{g})$} \\
\hline Kipas Merah (G0) & $16,454 \mathrm{ab}$ \\
\hline Grobogan (G1) & $18,827 \mathrm{c}$ \\
\hline Mutan A1 (G2) & $16,077 \mathrm{a}$ \\
\hline Mutan A7 (G3) & $17,248 \mathrm{abc}$ \\
\hline Mutan A11 (G4) & $18,585 \mathrm{c}$ \\
\hline Mutan A14 (G5) & $16,813 \mathrm{ab}$ \\
\hline $\mathrm{BNT}_{0,05}=$ & 1,89 \\
\hline $\mathrm{KK}=$ & $5,99 \%$ \\
\hline
\end{tabular}

Dari penelitian ini dapat diketahui bahwa genotipe mutan A11 sangat 
sesuai dan cocok untuk dibudidayakan pada kondisi lahan dan iklim di desa Lampahan Kabupaten Bener Meriah, kemungkinan juga bisa dibudidayakan pada kondisi yang serupa.

\section{KESIMPULAN}

Rata-rata tinggi tanaman cenderung lebih tinggi pada tetua Kipas Merah (G0), jumlah cabang pertanaman terbanyak dimiliki oleh mutan A7 (G3), dan jumlah cabang produktif terbanyak dimiliki oleh tetua Kipas Merah (G0). Tetua Kedelai Kipas Merah (G0) paling cepat berbunga dibandingkan genotipe lain yang diuji. Berat 100 biji tertinggi terdapat pada varietas Grobogan (G1) dan mutan A11 (G4). Mutan A11 (G4) juga merupakan genotipe dengan berat biji perbedeng tertinggi. Dengan demikian maka mutan A11 (G4) merupakan yang terbaik dari beberapa genotipe mutan $\mathrm{M}_{5}$ yang diuji.

\section{DAFTAR PUSTAKA}

Adisarwanto. 2014. Budidaya kedelai Tropika. Penebar swadaya. Jakarta. Hal.5-25.

Handara, N., Suharsono dan Mustikarini. E.D. 2014. Uji adaptasi galur harapan kedelai di lahan podsolik merah kuning di kabupaten Bangka. Jurnal Pertanian dan Lingkungan. 3(2): 1-48.

Kementerian Pertanian. 2020. Laporan Kerta Kementerian Pertanian tahun 2019. http://ppid.pertanian.go.id/. Diakses tanggal: 15 Desember 2020

Krisnawati. 2017. Kedelai sebagai Sumber Pangan Fungsional. Jurnal Iptek Tanaman Pangan Vol. 12 (1):1-2.

Purba, K., Bayu, E., \& Nuriadi, I. (2013). Induksi Mutasi Radiasi Sinar Gamma pada Beberapa Varietas Kedelai Hitam (Glycine Max (L.) Merrill). Jurnal Agroekoteknologi
Universitas Sumatera Utara, 1(2), 94420.

https://doi.org/10.32734/jaet.v1i2. 1530.

Rahmat, F., Mayani, N., \& Zuyasna, Z. (2018). Uji Daya Hasil Kedelai (Glycine max (L.) Merril) Varietas Kipas Merah Mutan Generasi Ke3 (M3) di Kebun Percobaan Fakultas Pertanian. Jurnal Ilmiah Mahasiswa Pertanian. https://doi.org/10.17969/jimfp.v3i 2.7477

Syukur, M., S. Sujiprihati, dan R. Yunianti. 2012. Teknik Pemuliaan Tanaman. Penebar Swadaya, Jakarta.

Zuyasna, Effendi, Chairunnas, dan Arwin. 2016. Efektivitas Polietlena Glikol Sebagai Bahan Penyeleksi Kedelai Kipas Merah Bireun yang Diiradiasi Sinar Gamma Untuk Toleransi Terhadap Cekaman Kekeringan. J. Floratek ISSN No. 1907- 2686 Vol.11, No 1: 66-74 